\title{
Letter to the editor about the paper by Gensicke et al. on the measurement of intracranial thrombus permeability in acute stroke
}

\author{
Karl-Olof Lövblad ${ }^{1}$
}

Received: 26 November 2019 / Accepted: 4 December 2019 / Published online: 13 December 2019

(C) Springer-Verlag GmbH Germany, part of Springer Nature 2019

We read with great interest the paper by Gensicke et al [1] on the measurement of intracranial thrombus permeability in acute stroke. Indeed, this topic is in our opinion of utmost relevance. Indeed, while we have seen great progress in the acute treatment of stroke due to the increased positive outcomes with endovascular clot removal, very little attention has been paid to the clot itself until recently [2]. Indeed, neuroscience and neuroradiology research tended to focus initially on the presence or absence or penumbra that would be salvaged [3], then on the presence of collaterals, while neglecting that the target that we are actually treating at the moment is the thrombus itself. Its composition may have a role on the success one will have using one kind of technique; indeed, some more red blood cell clots may favorably respond to simple aspiration while other more fibrin-rich clots may require stent retrieval. It would be a great advantage for the interventional neuroradiologist if based on initial CT he could determine clot composition fast and in a more reliable way. This also will necessitate that advanced imaging techniques using CT and MR be used more aggressively by both diagnostic and interventional neuroradiologists on what is now their common turf of combat: ischemic stroke. While the clot itself may not be the answer since the aforementioned factors such as penumbral tissue and collaterals do play a risk, nevertheless it seems necessary to take observations such as those done in this paper into consideration.

Funding information Funding is from the Swiss National Science Foundation with grant number 182382.

Karl-Olof Lövblad

karl-olof.lovblad@hcuge.ch

1 Service de neuroradiologie diagnostique et interventionnelle, Département diagnostique, Hôpitaux Universitaires de Genève, 4 rue Gabrielle-Perret-Gentil, 1211 Hôpitaux Universitaires de Genève, Geneva, Switzerland

\section{Compliance with ethical standards}

Conflict of interest The authors declare that they have no conflict of interest.

Ethical approval NA

Informed consent NA

\section{References}

1. Gensicke H, Evans JW, Al Ajlan FS, Dowlatshahi D, Najm M, Calleja AL, Puig J, Sohn SL, Ahn SH, Poppe AY, Mikulik R, Asdaghi N, Field TS, Jin A, Asil T, Boulanger JM, Hill MD, Goyal M, Demchuk AM, Menon BK, INTERRSeCT Investigators (2019) Comparison of different methods of thrombus permeability measurement and impact on recanalization in the INTERRSeCT multinational multicenter prospective cohort study. Neuroradiology. https://doi.org/10.1007/s00234-019-02320-y

2. Luthman AS, Bouchez L, Botta D, Vargas MI, Machi P, Lövblad KO (2019) Imaging clot characteristics in stroke and its possible implication on treatment. Clin Neuroradiol:1-9. https://doi.org/10.1007/ s00062-019-00841-w. Review

3. Schlaug G, Benfield A, Baird AE, Siewert B, Lövblad KO, Parker RA, Edelman RR, Warach S (1999) The ischemic penumbra: operationally defined by diffusion and perfusion MRI. Neurology. 53(7): $1528-1537$

Publisher's note Springer Nature remains neutral with regard to jurisdictional claims in published maps and institutional affiliations. 